\title{
Japan's Experience in OFDI and Its Enlightenment to China
}

\author{
Zhenyu AN \\ Graduate School of Applied Information Technology, \\ Kyoto College of Graduate Studies for Informatics \\ Kyoto, Japan
}

\author{
Tongxin AN \\ School of Business \\ University of Jinan \\ Jinan, China
}

\begin{abstract}
Japan is the second economic powerhouse and the third economic giant in the present world and China is also the second economic giant. Both of the countries have made great contributions to the development of the world economy. From 1960 s to 1980 s, Japan realized the rapid development of the national economy and the dream of becoming a powerful country. Japan is continuing to expand the investment in the domestic market; Japan is developing OFDI at the same time. China has gone through more than thirty years of reform and opening up, the "bring in" is growing rapidly, simultaneously China is trying to develop "going out". Based on the analysis of the development process and the experience of Japanese OFDI, the thesis combined the actual of developing the OFDI in China and putted forward some measures definitely, such as China's OFDI should focus on manufacturing, integrate the manufacturing and service, cultivate the core technology actively, produce an advantage of the brand, promote the development of the diversification and mesh simplification of the investment areas.
\end{abstract}

Keywords-Sino-Japanese OFDI; Location selection; Industry selection; Technological innovation

\section{INTRODUCTION}

In 2010, China's GDP has surpassed Japan and china become the second largest economy in the world. Meanwhile, China and Japan are both major countries in direct investment in the present world. As an economically developed country, Japan has accumulated rich experience in the development of OFDI. For example, Japan has a higher degree of diversification in the aspect of the location selection of Japanese foreign direct investment, and Japan avoid trade friction effectively by OFDI, promote the optimization and upgrading of domestic industrial structure effectively etc. These experiences can provide meaningful reference to the development of Chinese OFDI, which is entering the new normal.

\section{THE DEVELOPMENT AND EXPERIENCE OF JAPANESE OFDI}

\section{A. The process of Japanese development of OFDI}

After World War II, the development of Japanese OFDI has gone through five different periods. From 1951 to 1970, it was the first period, under the background of economic revival and

This paper is one of the positive results on the Chinese social science fund project: Research on Marginal Transition Path of China's Manufacturing Export Growth under the Constraint of Energy and Environment (Grant No: 16BJY076); One Asia Foundation, one of a series of achievements in the Research of International Cooperation and the Development of the Asian Community. rapid development, Japan was trying to develop OFDI with resource opening because of the lack of domestic resources. Because the Japanese lacked the funds and the Japanese government carried out a strict exchange control, however, the number and size of Japanese foreign direct investment was very small during this period, and the investment was mainly in the national projects and resources development in developing countries. The second period was from 1971 to 1980, in this period the foreign direct grew at low speed .Due to the outbreak of the oil crisis, Japan had the farthest dependence than the other developed countries, which led to the cost of high energy consumption products raise drastically. The raise of the prices led to the decrease of the demand, and the economic slowdown led to the increase of Japanese foreign direct investment was slow. The third period was from 1980 to 1991, during this period, Japan realized the second time of the development of foreign direct investment rapidly, and average annual flow of Japanese foreign direct investment soared to $\$ 22$ billion. During this period, Japan extended the foreign investment mainly to deal with the contention to the Asian market with the occident, and produced a synergy of the upgrade of Japanese domestic industry meanwhile increased the foreign direct investment of the third industry. The fourth period was from 1992 to 1999, which was the second adjustment period of Japanese foreign direct investment. After the bubble economy, the Japanese economy got into a longtime downturn in 1990s and most Japanese companies were hard to borrow money from banks with land and real estates, and then the downturn impacted Japan's foreign direct investment. The fifth period is from 2000 to the present, which is the period of Japanese foreign direct investment recovery and development. During this period, Japan's foreign direct investment is growing and expanding constantly, and overseas markets are also expanding ${ }^{[1]}$.

\section{B. The main experience of Japan's development of OFDI}

1) Japanese OFDI has promoted the transformation of the industrial structure from resource intensive industries to laborintensive industries, and then to the heavy and chemical industries. From 1950s to 1960s, Japanese OFDI was mainly resource intensive, and Japan's investment sector was mainly centered in the energy development sector, especially focused on the resource development in Asia and oil investment in the Middle East. In 1970s, Japanese OFDI was mainly based on heavy chemical industry. Because of the oil crisis arose twice and the high energy consumption and high pollution 
characteristics of heavy chemical industry, however, some heavy chemical industries had to be transferred to overseas because the development advantages of them in Japan were difficult to exhibit. At the same time, with the development of Japan's economy, the labor intensive industry which developed relying on cheap labor gradually lost its competitive advantage in the early days. Against this background, according to the marginal industry theory of Kiyoshi Kojima, Japanese enterprises shifted labor-intensive industries to Asian countries which have cheap labor force.

2) Japanese OFDI has helped domestic enterprises effectively avoid trade frictions with European and American countries. In 1968, the trade friction between Japan and Occident was growing in intensity after Japan became the second largest economic power in the world, especially in the late 1970s. In order to alleviate the trade friction effectively, Japan began to expand the scale of OFDI, and formed the climax of the development of foreign direct investment ${ }^{[2]}$. Japan shifted part of the export capability by investing directly in Asia, and exported to Europe and the United States to avoid trade frictions in such a roundabout way. The OFDI of developed countries such as the United States were born to avoid severe trade protection policies effectively, and ensure the stable export market. At the same time, Japan has begun to expand the investment in services in the United States.

3) Japanese OFDI has certainly improved the efficiency of investment by developing the networks ${ }^{[3]}$. In terms of location selection and industry development, Japanese companies achieved the goal of inserting into the production network from some major areas in the whole world through the way of OFDI. Japanese multinational corporations which were located mainland connected the production network with North America, Europe and Asia three regional by providing products planning, core technology and components to overseas local corporate, constructed a new network model of foreign direct investment certainly. From the point of marketing, Japanese enterprises have formed a regional purchasing and selling model by establishing the local legal persons in the investment destinations.

\section{THE DEVELOPMENT AND CHARACTERISTICS OF CHINA'S OFDI}

\section{A. Recent development of China's OFDI}

With the rapid development of China's economy, China's OFDI has achieved 13-year continuous growth, and the traffic in 2015 was 54 times as much as 2002, the average annual growth rate was $35.9 \%$. According to statistics, in 2015, China's OFDI reached $\$ 145.67$ billion, an increase of $18.3 \%$, the scale surpassed Japan and ranked second in the world at the first time.

According to statistics, by the end of 2015, the stock of China's OFDI amounted to \$1097.86 billion, increased $\$ 215.22$ billion than the end of 2014 , and accounted for the share of global FDI outflow of stocks jumped to $4.4 \%$, the ranking increased from twenty-fifth to eighth. China's OFDI started late and entered a period of rapid growth after 2010. China's stock size reach $90 \%$ of Japan's already, but also has large gap with the United States, Germany and Britain, and the stock at the end of 2015 is only equivalent 18.3\%, 60.6\%, $71.4 \%$ of the United States, Germany and Britain at the same period $^{[4]}$.

From the point of investment industry choice, China's OFDI covers 19 major categories of industries in 2015. The major investment industries include leasing and commercial services, manufacturing, finance, wholesale and retail, information transmission / software and information services. The manufacturing industry mainly focused on automotive industry, computer communications and other electronic equipment manufacturing industry, special equipment manufacturing industry, chemical raw materials and chemical products manufacturing, pharmaceutical manufacturing, textile industry, railway / ship / aerospace and other transportation equipment manufacturing industry and so on. At the same time, the OFDI of China's financial institutions has been active in recent years. By the end of 2015, the total amount of OFDI had reached $\$ 24.43$ billion, and the direct investment flowed to overseas financial enterprises amounted to $\$ 23.7$ billion.

From the point of view of investment location choice, until the end of 2015, China's investment stock is $\$ 768.9$ billion in Asia, accounting for as high as $70 \%$, of which the main investment countries and regions are Hong Kong, India, Singapore, South Korea, Thailand, Japan, Iran, etc. In Latin America, China's investment stock is $\$ 126.32$ billion, accounting for $11.5 \%$. The main countries and regions of investment are the Cayman Islands, the British Virgin Islands, Brazil, Argentina, Mexico, etc. In Europe, China's investment stock is $\$ 83.68$ billion, accounting for $7.6 \%$; the main countries of investment are mainly Holland, Britain, Russia, Germany, and France and so on. In North America, China's investment stock is $\$ 52.18$ billion, accounting for $4.8 \%$ of China's total foreign investment stock. In Africa, China's investment stock is $\$ 34.69$ billion, accounting for $3.2 \%$; the main countries of investment are South Africa, Congo (DRC) and so on. In Oceania, China's investment stock is $\$ 32.9$ billion, accounting for $2.9 \%$, and the main countries of investment are Australia, New Zealand and so on.

\section{B. The development characteristics of China's OFDI}

1) Characteristics of industry selection of China's OFDI

China's OFDI industry has spread all over the three major industries. The proportion of agriculture, forestry, animal husbandry and fishery in the first industry was small, and at the highest it was only 5.25\%. The second industry used to be the main investment industry of China's OFDI. In 2006, the mining industry accounted for $40.35 \%$ of China's OFDI flows, and ranked first in those days. Manufacturing peaked at $18.6 \%$ of China's OFDI flows in 2005 and has been on the rise since it dropped to lowest at $3.16 \%$ in 2008 . The third industry is the main industry of OFDI in the development of China, until the end of 2015, in terms of three-industry composition, the third industry accounted for $75.2 \%$ of the stock of China's OFDI (the first industry accounted for $0.8 \%$, the second industry accounted for 24\%). In the third industry, leasing and commercial services even reached $40.30 \%$ in 2005, which also has been the main investment area of China's OFDI all the time. At the same time, China's investment in technology-intensive 
projects has been increasing, which is the new direction of China's development of OFDI ${ }^{[4]}$. At the beginning, China's OFDI takes the traditional mining industry, manufacturing, wholesale and retail, leasing and business services as the center, then gradually expand to the construction industry, transportation, storage and postal industry, real estate, education, culture and other industries, the industrial fields continue to expand and content constantly rich.

\section{2) The location choice characteristics of china's OFDI}

The location choice of china's OFDI is becoming more and more extensive. According to statistics, until the end of 2015, China's OFDI has set up 30,800 enterprises in the global 188 countries (regions) and there is an increase of more than 1,100 enterprises compared with 2014. These enterprises widely distributed in more than $80 \%$ countries and regions worldwide, with a coverage of overseas enterprises of Asia is $97.9 \%$, Europe is $87.8 \%$, Africa is $85 \%$, North America is 75\%, Latin America is $67.3 \%$ and Oceania is 50\%. From 2003 to 2003, Asia accounts for $60 \%$ to $70 \%$ of China's OFDI and is the highest share region in the Chinese OFDI, while Hong Kong is the region with the highest proportion of China's OFDI in Asia.

From the analysis of the investment stock in country (region) , according to statistics, until the end of the 2015, the top 20 countries (regions) of China's OFDI stock reached 988 billion 59 million US dollars, accounting for $89.8 \%$ of China's OFDI stock. The 20 countries are: Hong Kong, Cayman Islands, British Virgin Islands, the United States, Singapore, Australia, Holland, Britain, etc.

\section{THE INSPIRATION OF JAPAN’S DEVELOPMENT OF OFDI TO CHINA}

In going out a dozen years in China, no matter in quantity scale, investment countries and the region, or the investment industry and other aspects it made great achievements, but compared with developed country Japan, there is still a large gap. We can get the following enlightenment from Japanese OFDI.

\section{A. China should take manufacturing as its center and balance development of other industries}

Under the background of economic globalization, the economic development of most countries in the world has presented a trend of shifting to the service industry. The shift of the focus of economic industry will inevitably shift from the global industrial structure centered on the industrial economy to a global industrial structure with a service-oriented economy as the center. China should seize the opportunity, conform to the new development trend of the global industrial structure, accelerate the upgrading of China's traditional industrial structure and develop its new industrial structure. Although the appreciation of the RMB has a positive impact on Chinese OFDI, such as business services and leasing industry, so that OFDI has increased dramatically, but the service level of these industries is still low, and China's investment in high-quality service industry has not formed a lasting influence. At the same time, in recent years, China's manufacturing industry has gained high recognition in developing countries and even has a better reputation in developed countries. To build the brand of the Chinese nation, making a high level of manufacturing and services to the world is the key to enhance China's new industries, which will help improve the international competitiveness of Chinese manufacturing industry, promote China to achieve industrial upgrading. China in some ways especially compared with the 70-80 s of the 20th century Japan's competitiveness of manufacturing industry in the global, there are obvious shortcomings. At that time Japan relies on advanced manufacturing technology and perfect industry chain structure, moving parts manufacturing to labor productivity cost cheaper in Southeast Asia and Africa, effective for upgrading the local industrial structure optimization. At present, China's food industry, solar energy industry, electronic communications industry, aerospace technology, etc., already have a strong comparative advantage. China should strive to play the comparative advantages, center the manufacturing industry as the center, taking account the development of service industry foreign investment at the same time, learn from the advanced management experience of developed countries such as Japan, promote new energy transformation, and effectively avoid trade friction.

\section{B. Chinese enterprises should actively cultivate core technology and strive to play the brand advantage}

In the process of "going out", Japanese enterprises have realized the transformation from big to strong, mainly relying on their own core technology and brand advantages, such as Toyota Corp, Panasonic Corp and so on. Although the number of China's foreign investment has increased rapidly, it still lacks its core technology and has not yet formed a brand advantage. During the development of economy in the world china as a power country, in order to expand its influence in the international market, it is necessary to learn from the Japanese experience, really improve the ability of independent innovation, to establish brand awareness, continue to play and create brand advantage. At the same time, in the process of "going out", Chinese enterprises also must strive to cultivate management talents who master the international market rules, and comprehensively improve their learning ability, innovation ability and management level, and establish and improve the corresponding risk assessment system.

\section{China should strive to promote the development of regional diversification and gridding of OFDI}

For a long time, the Japanese economy overly reliance on the U.S. economy, which has caused Japan's OFDI to be overly single and concentrated in the United States. At the end of the 1980s, the continued appreciation of the yen and the depreciation of the dollar will inevitably lead to a decline in the real rate of return for Japanese foreign direct investment, which has exacerbated Japan's "bubble economy" to a certain extent. Relative to the Japanese foreign investment failure lessons, the region of China's OFDI has achieved diversified development, which greatly weakened the risk caused by the appreciation of the RMB, however, China's foreign direct investment mainly concentrated in the market economy is not well developed regions like Asia and Latin America, while in the mature market economy like North America and Europe, the proportion of direct investment remains relatively low. The current debt woes of Europe and the United States provides a 
good opportunity for China’s "going out", China should grasp the opportunities, the implementation of the decentralization of investment, actively promote China's diversified investment in developed countries in Europe and America, so as to achieve balanced development of China's OFDI in different countries and regions and improve its competitiveness under the influence of globalization. At the same time, in the process of OFDI, China should learn from Japan's foreign investment experience, adopt the strategy of global gridding development, strengthen the research of regional and industry selection of foreign investment, promote industrial economy and regional positioning integration development, and determine the reasonable location structure of investment and industrial structure, to maximize achieve the benefits of OFDI.

\section{CONCLUSION}

Despite China's OFDI started relatively late, china as a big developing country has developed rapidly in recent years. At the same time, compared with developed countries like Japan, there are numerous defects in investment location choice and industry choice and etc. Therefore China should learn the Japanese successful experience, develop the comparative advantages, study and formulate the strategy that Chinese OFDI should as the center of manufacturing industry both the industry development, promote regional diversification and grid development of foreign direct investment.

\section{REFERENCES}

[1] IIDA Kazuto. The expansion of Japanese OFDI and the establishment of global capital [J]. Journal of political economy, 2010, 78 (5-6):1-39

[2] MA Wenxiu, YANG Xi, The effect of Japanese OFDI on easing JapanUS trade friction and Its Enlightenment [J]. Japanese Studies, 2008, (01):31-37(In Chinese)

[3] SU Hang. The networking development of Japanese OFDI and Its Enlightenment [J]. Japanese Studies, 2015, (02):93-108(In Chinese)

[4] LIU Hong. The present situation, characteristics and existing problems of Chinese OFDI [J]. Overseas Investment Export Credits, 2017, (01):11-15(In Chinese) 